\title{
Effects of Oxygen Tension on Pumping, Filtration and Oxygen Uptake in the Ascidian Phallusia mammillata
}

\author{
A. Fiala-Médioni \\ Université Paris VI, Laboratoire Arago, F-66650 Banyulus-sur-Mer, France
}

ABSTRACT: The effects of declining oxygen tension on pumping, filtration and oxygen uptake were studied simultaneously in Phallusia mammillata (Cuvier, 1815). Identical effects were observed on rates of pumping and filtration; these remain constant until the oxygen tension $\left(\mathrm{pO}_{2}\right)$ falls to a mean level of $119 \mathrm{~mm} \mathrm{Hg}$ (concentration $=3.85 \mathrm{ml} \mathrm{O}_{2} 1^{-1}$ ) and then decrease. Below a $\mathrm{pO}_{2}$ of $98 \mathrm{~mm} \mathrm{Hg}\left(3.18 \mathrm{ml} \mathrm{O}_{2} 1^{-1}\right)$ the rates decrease more rapidly and become more variable. No particular rhythms emerged. Below a $\mathrm{pO}_{2}$ of $119 \mathrm{~mm} \mathrm{Hg}$, rapid and rhythmic variations in the diameter of the cloacal siphon produce a pseudorhythm. Filtering efficiency stays constant, with values of 77 to $79 \%$; the mechanism of mucus formation is not affected down to a $\mathrm{pO}_{2}$ of $98 \mathrm{~mm} \mathrm{Hg}$. Below a mean $\mathrm{pO}_{2}$ of $119 \mathrm{mg} \mathrm{Hg}$ - the critical tension - oxygen uptake decreases; $P$. mammillata fails to regulate oxygen consumption, and becomes a 'conformer'.

\section{INTRODUCTION}

As has been documented in Volume I of 'Marine Ecology', dissolved gases are of paramount importance for marine organisms (Fogg, 1972; Gunkel, 1972; Kalle, 1972; Wilber, 1972). Oxygen tension may affect the activity of filter-feeders. In lamellibranch molluscs, the reaction to declining oxygen tension is a complex phenomenon related to environmental variation - e. g. temperature, food ration, etc. (Bayne, 1971a, b; MacLusky and Stirling, 1975; Taylor and Brand, 1975). Few experimental data exist in the literature on the activity of ascidians, and none on the influence of oxygen tension on pumping and filtration rates. With an experimental apparatus previously described (FialaMédioni, 1973, 1978a, b), which measures pumping and filtration rates simultaneously, it has been possible to study the activity of Phallusia mammillata under conditions of declining oxygen tension.

\section{MATERIAL AND METHODS}

Phallusia mammillata (Cuvier, 1815) was selected because it performs well under experimental conditions. Four different individuals were used for the 4 experiments of 27 to $31 \mathrm{~h}$ each. They were collected by SCUBA-diving in the harbour of Banyuls-sur-Mer (western Mediterranean coast of France) where this species is abundant on various hard substrata. The characteristics of the individuals used are summarized in Table 1.

Table 1. Phallusia mammillata. Characteristics of individuals collected in Banyuls-sur-Mer harbour. Bs: buccal siphon; Cs: cloacal siphon.,,-+++ : genital products absent, present, abundant, respectively

\begin{tabular}{|c|c|c|c|c|c|c|}
\hline \multirow{2}{*}{$\begin{array}{l}\text { Experiment } \\
\text { No. and col- } \\
\text { lection depths }\end{array}$} & \multirow{2}{*}{$\begin{array}{l}\text { Length/width } \\
\qquad(\mathrm{cm})\end{array}$} & \multicolumn{3}{|c|}{ Dry weight $(g)$} & \multirow{2}{*}{$\begin{array}{c}\text { Siphon of diameter } \\
\text { BS/CS } \\
\text { (mm) }\end{array}$} & \multirow{2}{*}{$\begin{array}{l}\text { Sexual } \\
\text { activity }\end{array}$} \\
\hline & & Test & Organs & Tatal & & \\
\hline $13 \mathrm{~m}$ & $12.0 / 5.5$ & 1.807 & 0.848 & 2.655 & $10.0 / 7.0$ & ++ \\
\hline $24 \mathrm{~m}$ & $11.0 / 5.5$ & 1.642 & 0.976 & 2.618 & $15.0 / 9.0$ & - \\
\hline $35 \mathrm{~m}$ & $11.5 / 4.0$ & 1.377 & 0.620 & 1.997 & $12.0 / 6.5$ & + \\
\hline $42 \mathrm{~m}$ & $10.5 / 5.0$ & 1.632 & 0.780 & 2.412 & $9.5 / 7.0$ & + \\
\hline
\end{tabular}


Two methods were used simultaneously: a direct method using a hot film probe and an indirect method previously described (Fiala-Médioni, 1973, 1978a). Water velocities were calculated according to the linearized Collis and Williams law, as detailed in an earlier paper (Fiala-Médioni, 1978b). For the only probe used, the root mean square (Rms) error obtained by computer with the calibration data was $1.71 \%$.

The temperature of the experimental medium was maintained constant $\left(15^{\circ} \mathrm{C} \pm 1 \mathrm{C}^{\circ}\right)$ as well as the concentration $\left(20.10^{6}\right.$ cells per liter $\left.\pm 5 \%\right)$ of the algae (Monochrysis lutheri); $\mathrm{pH}$ and salinity were controlled at the beginning, during, and at the end of each experiment (Table 2). Oxygen tension was monitored according to a polarographic method, using an oxygen electrode connected to a 'Radiometer' analyser; every hour, readings were taken of partial pressure in the experimental medium. The $\mathrm{pO}_{2}$ values were corrected with values obtained in a blank experiment (same conditions, without test individual).

\section{RESULTS}

\section{Water-current Velocities}

The average water velocities varied between less than 3 and $7.2 \mathrm{~cm} \mathrm{sec}^{-1}$, the maximum being $23.2 \mathrm{~cm}$ $\sec ^{-1}$ (Table 3 ). Water velocities tended to decrease with time but, because the diameter of the cloacal siphon decreased simultaneously, water-velocity decrease was not as obvious as it would have been had the cloacal siphon remained fully open.

\section{Pumping Rates}

Pumping rates varied between 3224 and $5766 \mathrm{ml} \mathrm{h}^{-1}$ (Fig. 1); expressed as dry weight of organs, these rates were: 5097 to $6391 \mathrm{ml} \mathrm{h}^{-1} \mathrm{~g}^{-1}$ (Table 3). In all experiments, pumping rates decreased after 12 to $15 \mathrm{~h}$. Three phases emerged: (1) from a normal level of oxygen tension down to $\mathrm{pO}_{2}$ mean values of $119 \mathrm{~mm} \mathrm{Hg}$ (concentration of $3.85 \mathrm{ml} \mathrm{O}_{2} 1^{-1}$ ), pumping rates displayed a mean value of $6012 \mathrm{ml} \mathrm{h}^{-1} \mathrm{~g}^{-1}$ and a small coefficient of variation $(<15 \%)$; (2) down to a $\mathrm{pO}_{2}$ mean value of $98 \mathrm{~mm} \mathrm{Hg}$ (concentration of $3.18 \mathrm{ml} \mathrm{O} 1^{-1}$ ), mean pumping rates decreased to $5307 \mathrm{ml} \mathrm{h}^{-1} \mathrm{~g}^{-1}$ and variability rose to between 15 and $30 \%$; (3) in the third phase the coefficients of variation exceeded $30 \%$; only a few values could be calculated; after 19 or $21 \mathrm{~h}$ the velocities of the water current decreased below $3 \mathrm{~cm}$ $\sec ^{-1}$; this is the minimum value for calibration of the probe.

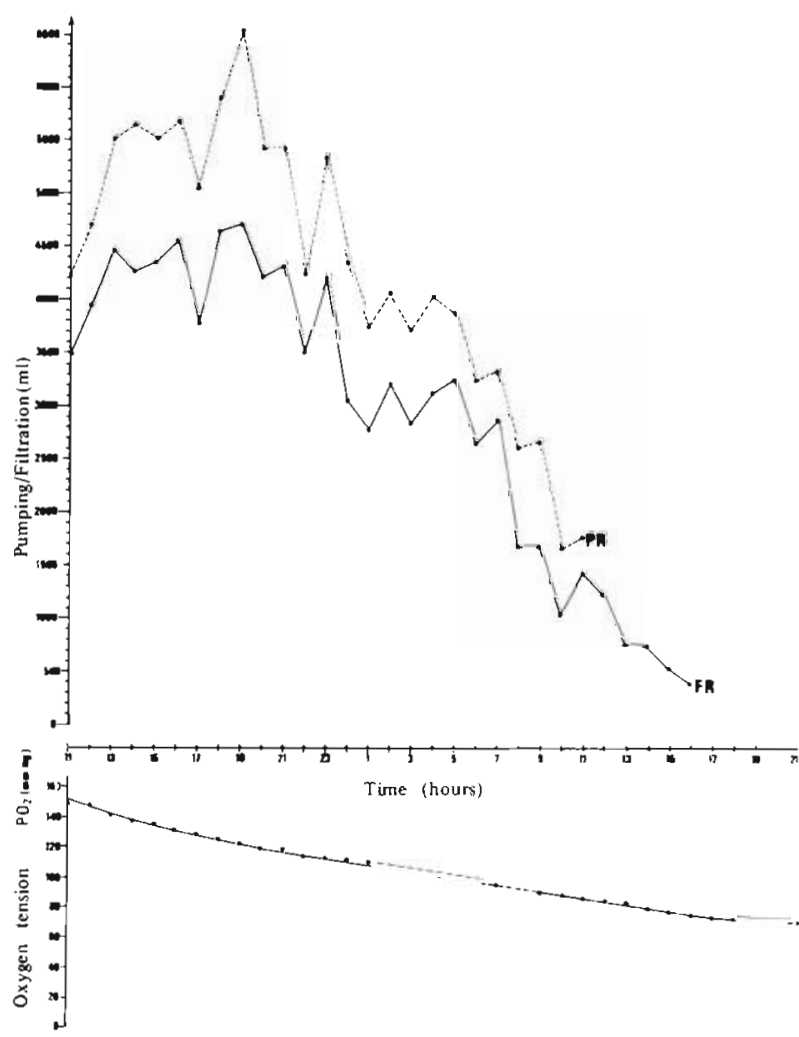

Fig. 1. Phallusia mammillata. Rates of pumping (PR) and filtration (FR) in relation to oxygen tension

Table 2. Phallusia mammillata. Experimental conditions. Min: minimum, Max: maximum temperature; $S_{0}$ : initial salinity; $S_{F}$ final salinity; $\mathrm{O}_{20}$ : initial oxygen concentration; $\mathrm{O}_{2 \mathrm{~F}}$ : final oxygen concentration; $\mathrm{pH}_{0}$ : initial $\mathrm{pH}_{\text {; }} \mathrm{pH}_{\mathrm{F}}$ : final $\mathrm{pH}$. Concentration of Monochrysis lutheri in the experimental medium was $20 \cdot 16^{6}$ cells $1^{-1}( \pm 5 \%)$

\begin{tabular}{|c|c|c|c|c|c|c|c|c|c|}
\hline \multirow{2}{*}{$\begin{array}{c}\text { Experiment } \\
\text { No. }\end{array}$} & \multicolumn{3}{|c|}{ Temperature $\left({ }^{\circ} \mathrm{C}\right)$} & \multicolumn{2}{|c|}{ Salinity $(\%)$} & \multicolumn{2}{|c|}{$\begin{array}{l}\text { Oxygen concentration } \\
\qquad\left(\mathrm{ml} \mathrm{O} 1^{-1}\right)\end{array}$} & \multicolumn{2}{|c|}{$\mathrm{pH}$} \\
\hline & Min. & Max. & Mean & $\mathrm{S}_{0}$ & $\mathrm{~S}_{F}$ & $\mathrm{O}_{20}$ & $\mathrm{O}_{2 \mathrm{~F}}$ & $\mathrm{pH}_{0}$ & $\mathrm{pH}_{\mathrm{F}}$ \\
\hline 1 & 14.7 & 15.2 & 15.06 & 37.92 & 38.20 & 5.28 & 2.44 & 7.8 & 7.5 \\
\hline 2 & 14.7 & 15.8 & 15.17 & 37.80 & 38.41 & 5.09 & 3.07 & 7.9 & 7.4 \\
\hline 3 & 14.8 & 15.3 & 14.98 & 37.97 & 38.32 & 4.99 & 2.60 & 8.0 & 7.3 \\
\hline 4 & 14.9 & 15.3 & 15.13 & 37.88 & 38.11 & 5.15 & 2.24 & 8.1 & 7.5 \\
\hline
\end{tabular}




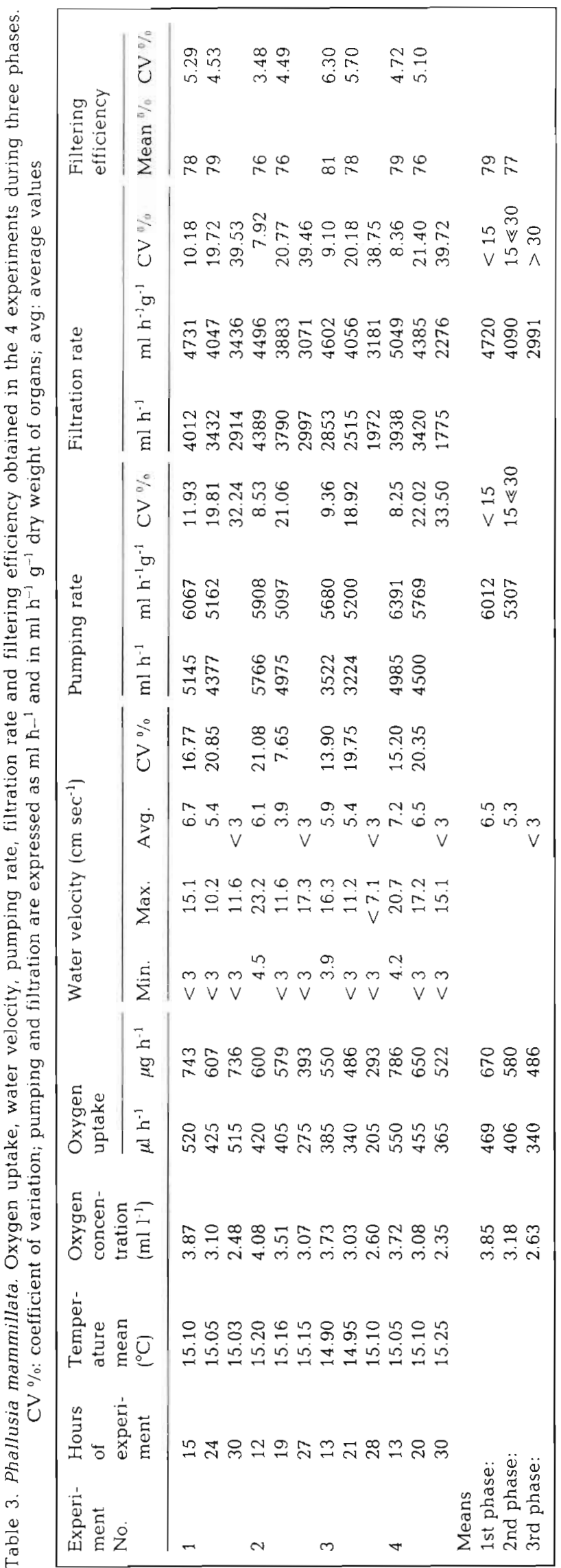

\section{Pumping Rhythm}

Pumping rates did not display any particular rhythm (Fig. 1); they decreased with oxygen tension after the first phase. In the second phase, the siphons were sometimes closed, while the diameter of the cloacal siphon became more variable. In probe recordings, a pseudo-rhythm was observed in relation to the rhythmic movements of the orifice of the cloacal siphon. These movements became more frequent in the third phase (below $\mathrm{pO}_{2}=98 \mathrm{~mm} \mathrm{Hg}$ ) (Fig. 2).
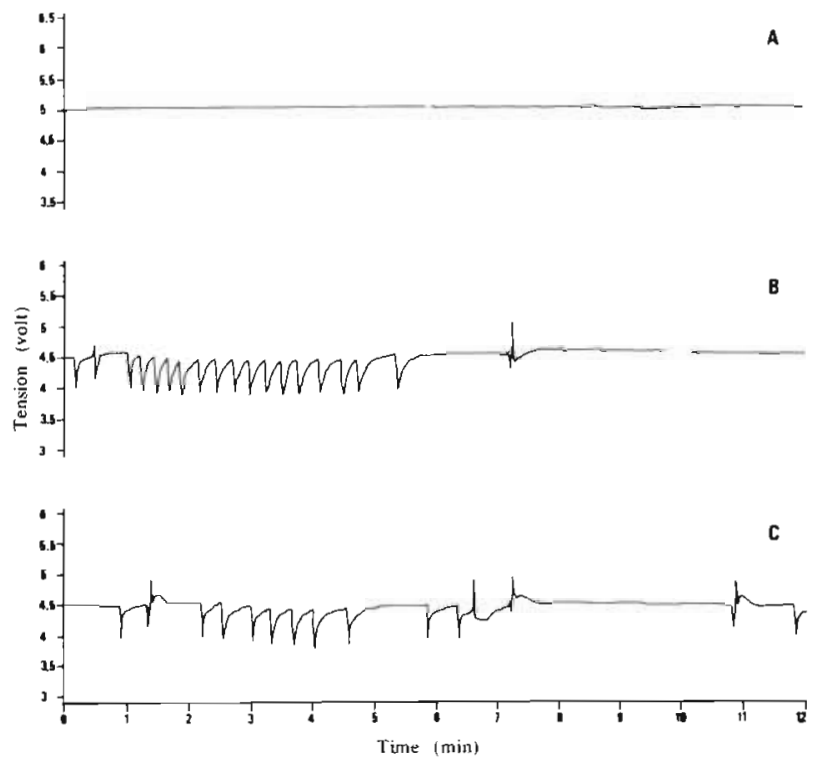

Fig. 2. Phallusia mammillata. Recordings of water-current velocity obtained with Probe $A$ : down to mean oxygen tension of $119 \mathrm{~mm} \mathrm{Hg} ; \mathrm{B}: \mathrm{pO}_{2}$ between 119 and $98 \mathrm{~mm} \mathrm{Hg}$ : $: \mathrm{pO}_{2}$ values lower than $98 \mathrm{~mm} \mathrm{Hg}$. The pseudo-rhythm observed in $B$ and $C$ is related to fast and rhythmic changes in cloacal siphon diameter

\section{Rate and Rhythm of Filtration}

Filtration rates showed the same response as pumping rates: they were maintained at a mean value of $4720 \mathrm{ml} \mathrm{h}^{-1} \mathrm{~g}^{-1}$ dry weight of organs (Table 3 ); with coefficients of variation lower than $15 \%$, down to a mean $\mathrm{pO}_{2}$ of $119 \mathrm{~mm} \mathrm{Hg}$ (concentration of $3.85 \mathrm{ml}$ $\left.\mathrm{O}_{2} 1^{-1}\right)$. Below this $\mathrm{pO}_{2}$ value down to $\mathrm{pO}_{2}$ of $98 \mathrm{~mm} \mathrm{Hg}$ ( $3.18 \mathrm{ml} \mathrm{O} \mathrm{O}_{2} \mathrm{~L}^{-1}$ ) it decreased with declining oxygen tension, to a mean value of $4090 \mathrm{ml} \mathrm{h}^{-1} \mathrm{~g}^{-1}$ and a coefficient of variation between 15 and $30 \%$. At still lower $\mathrm{pO}_{2}$ levels, variability exceeded $30 \%$ with a mean rate of $2991 \mathrm{ml} \mathrm{h}^{-1} \mathrm{~g}^{-1}$.

\section{Filtering Efficiency}

Pumping and filtration rates gave quasi-parallel curves (Fig. 1), clearly revealing a constant filtering 
efficiency. Values of 76 to $81 \%$ (mean $79 \%$ ) were obtained in the first phase (until $\mathrm{pO}_{2}$ at $119 \mathrm{~mm} \mathrm{Hg}$ ) and 76 to $79 \%$ (mean $77 \%$ ) in the second phase (until $\left.\mathrm{pO}_{2}=98 \mathrm{~mm} \mathrm{Hg}\right)_{i}$ both sets of values had a small coefficient of variation (mean $=4.95 \%$ ). Formation of the mucus sheet was not affected by declining oxygen tension, at least not down to a $\mathrm{pO}_{2}$ of $98 \mathrm{~mm} \mathrm{Hg}$. The decrease in filtration rate was thus related only to the decrease in pumping rates. a mean $\mathrm{pO}_{2}$ of $119 \mathrm{~mm} \mathrm{Hg}$ (a value which varies for different individuals between 110 and $158 \mathrm{~mm} \mathrm{Hg}$ ); below this value it becomes a 'conformer'. This critical tension is close to that reported by Fisher (1976) at $15^{\circ} \mathrm{C}$ for Styela plicata $(129 \mathrm{~mm} \mathrm{Hg})$.

In the first phase, oxygen uptake is not affected by decreasing oxygen tension, and varies between 385 and $550 \mu \mathrm{I} \mathrm{h}^{-1}\left(550\right.$ and $\left.786 \mu \mathrm{g} \mathrm{h}^{-1}\right)$ or 430 and $705 \mu \mathrm{I}$ $\mathrm{h}^{-1} \mathrm{~g}^{-1}$ organ dry weight, with a mean of $592, \mathrm{ul} \mathrm{h} \mathrm{h}^{-1} \mathrm{~g}^{-1}$

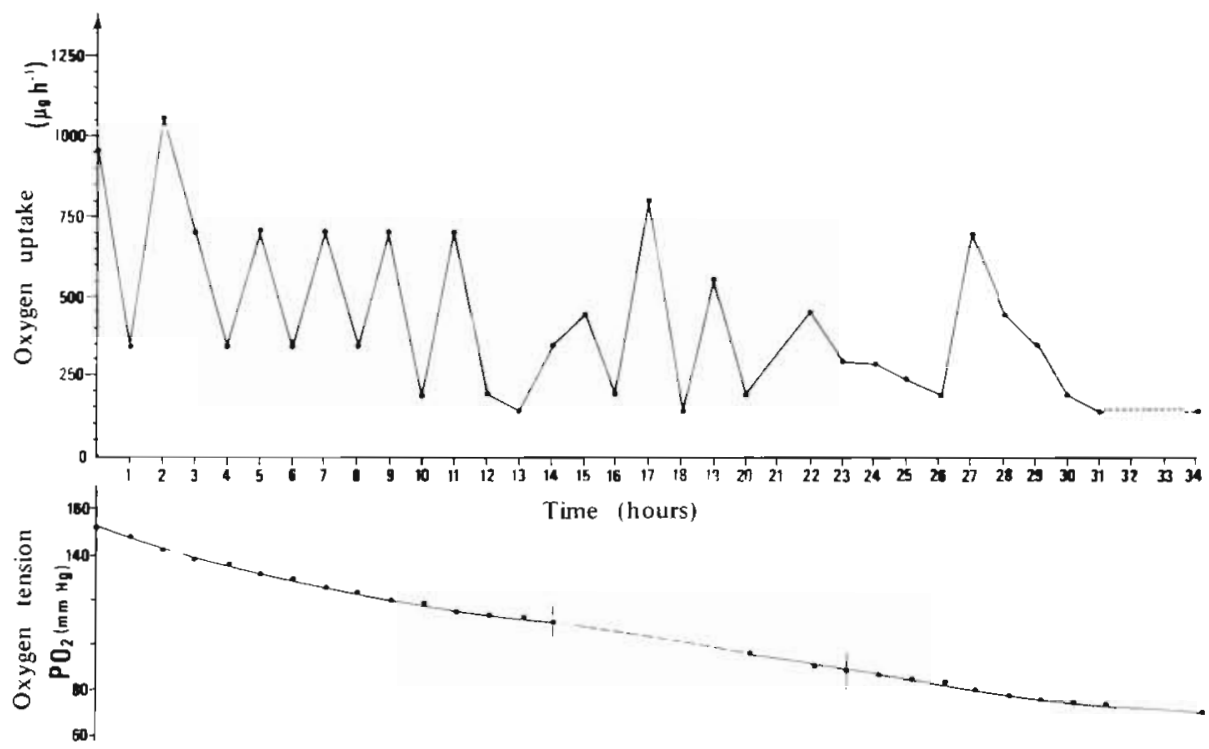

Fig. 3. Phallusia mammillata. Oxygen uptake expressed in micrograms per hour $\left(\mu \mathrm{g} \mathrm{h}^{-1}\right)$ in relation to oxygen tension

\section{Rate and Rhythm of Oxygen Uptake}

Oxygen uptake remained constant down to $\mathrm{pO}_{2}$ values of $70 \mathrm{~mm} \mathrm{Hg}$ only in one ascidian. In the other individuals, this rate was independent of oxygen decrease only down to a $\mathrm{pO}_{2}$ of $119 \mathrm{~mm} \mathrm{Hg}$ (concentration of $3.85 \mathrm{ml} \mathrm{O}_{2} 1^{-1}$ ), with values of 550 to $786 \mu \mathrm{g} \mathrm{h}^{-1}$. Below $118 \mathrm{~mm} \mathrm{Hg}$ the rate decreased, with a range of 486 to $650 \mu \mathrm{g} \mathrm{h}^{-1}$, and below $98 \mathrm{~mm} \mathrm{Hg}$ the values varied from 293 to $736 \mu \mathrm{g} \mathrm{h} \mathrm{h}^{-1}$. When expressed in relation to the dry weight of the organs, the mean rates of oxygen uptake were 846,732 , and $603 \mu \mathrm{g} \mathrm{h}^{-1} \mathrm{~g}^{-1}$. The values of oxygen uptake were irregular, with alternatively high and low values (Fig. 3).

\section{DISCUSSION}

Phallusia mammillata displays constant and normal rates of pumping, filtration and oxygen uptake down to a mean $\mathrm{pO}_{2}$ of $119 \mathrm{~mm} \mathrm{Hg}$. This value represents a critical tension for this species under the environmental conditions offered in our experiments. P. mammillata is able to regulate its activity ('regulator') down to
(614 and $1007 \mathrm{\mu g} \mathrm{h} \mathrm{g}^{-1} \mathrm{~g}^{-1}$ with a mean of $846 \mu \mathrm{g} \mathrm{h}^{-1} \mathrm{~g}^{-1}$ ). For Ciona intestinalis, Jørgensen (1952) gave values of 600 to $900 \mu \mathrm{l} \mathrm{h}{ }^{-1}$. Fisher's (1976) value at $15^{\circ} \mathrm{C}$ for Styela plicata was $300 \mu \mathrm{h} \mathrm{h}^{-1} \mathrm{~g}^{-1}$ organ dry weight.

Acknowledgements. I thank Professor H. Lacombe for his hospitality in the Physical Oceanography Laboratory (Paris) and M. Revault d Allones and J. C. Magenham for the computor analysis of calibration data of the probe; I am grateful to Mrs. S. Razouls for her advice about the polarographic apparatus and to Professor D. M. Ross for critically reading the English manuscript. This work was supported by CNRS (LA 117) and CNEXO (77.1615).

\section{LITERATURE CITED}

Bayne, B. L. (1971a). Oxygen consumption by three species of lamellibranch mollusc in declining ambiant oxygen tension. Comp. Biochem. Physiol, 40 A, 955-970.

Bayne, B. L. (1971b). Ventilation, the heart beat and oxygen uptake by Mytilus edulis L. in declining oxygen tension. Comp. Biochem. Physiol., 40 A, 1065-1085.

Fiala-Médioni, A. (1973). Ethologie alimentaire d'invertébrés benthiques filtreurs (Ascidies) I. Dispositif experimental. Taux de filtration et de digestion chez Phallusia mammillata. Mar. Biol., 23, 137-145. 
Fiala-Médioni, A. (1978a). Filter-feeding ethology of benthic invertebrates (Ascidians) III. Recording of water current in situ. Rate and rhythm of pumping. Mar. Biol., 45, 185-190.

Fiala-Médioni, A. (1978b). Filter-feeding ethology of benthic invertebrates (Ascidians) IV Pumping rate, filtration rate, filtering efficiency. Mar. Biol., 48, 243-249.

Fisher, T R. (1976). Oxygen uptake of the solitary tunicate Styela plicata. Biol. Bull. mar. biol. Lab., Woods Hole, 151, 297-305.

Fogg, G. E. (1972). Organic substances: plants. In O. Kinne (Ed.), Marine Ecology, Vol. I, Environmental Factors, Part 2. Wiley, London. pp. 1551-1563.

Gunkel, W. (1972). Organic substances: bacteria, fungi and bluegreen algae. In O. Kinne (Ed.), Marine Ecology, Vol. I. Environmental Factors, Part 2. Wiley, London. pp. 1533-1549.

Jørgensen, C. B. (1952). On the relation between water trans- port and food requirements in some marine filter feeding invertebrates. Biol. Bull. mar. biol. Lab., Woods Hole, 103, 356-363.

Kalle, K. (1972). Organic substances: general introduction. In O. Kinne (Ed.), Marine Ecology, Vol. I, Environmental Factors, Part 2. Wiley, London. pp. 1527-1531.

McLusky, D. and Stirling, A. (1975). The oxygen consumtion and feeding of Donax incarnatus and Donax spiculum from tropical beaches. Comp. Biochem. Physiol., $51 \mathrm{~A}_{1}$ 943-947

Taylor, A. C. and Brand, A. R. (1975). A comparative study of the respiratory responses of the bivalves Arctica islandica (L.) and Mytilus edulis L. to declining oxygen tension. Proc. $R$. soc. London, 190,443-456.

Wilber, C. G. (1972). Organic substances: animals. In $O$. Kinne (Ed.), Marine Ecology, Vol. I, Environmental Factors, Part 2. Wiley, London. pp. 1565-1577.

This paper was presented by Professor J.-M. Pérès; it was accepted for printing on June 11, 1979. 